\title{
Determination of stable isotope characteristics and natural radioactivity in drinking waters in Sandıklı basin (Afyonkarahisar-Turkey)
}

\author{
Sandıklı havzası (Afyonkarahisar-Türkiye) içme sularında doğal \\ radyoaktivite ve duraylı izotop özelliklerinin belirlenmesi
}

\author{
Fatma AKSEVER ${ }^{1 *}$ iD , Ayșen DAVRAZ2 ${ }^{\text {iD }}$, Remzi KARAGÜZEL ${ }^{3}$ iD \\ 1,2Department of Geological Engineering, Faculty of Engineering, Süleyman Demirel University, Isparta, Turkey. \\ fatmaaksever@sdu.edu.tr, aysendavraz@sdu.edu.tr \\ 3Department of Geological Engineering, Faculty of Mines, İstanbul Technical University, İstanbul, Turkey. \\ karaguzel@itu.edu.tr
}

\begin{abstract}
The Sandikl basin is located in the southwestern part of Turkey. In this paper, groundwater stable isotope analyzes were evaluated to understand the recharge of the aquifer system in the Sandlkl basin. For this, samples of groundwater were collected for two periods in 20092010 years and the stable isotope and natural radioactivity analyzes were made in the basin. The $\delta^{18} O$ and $\delta^{2} H$ contents of groundwaters in the region range from -8.08 to $-10.77 \%$ ond from-52.44 to $-69.53 \%$, respectively. The stable isotope data lie generally above the Global Meteoric Water Line and waters are meteoric origin. The tritium content of the groundwaters ranges from 0.00 to $4.20 \mathrm{TU}$ in dry period and from 0.30 to $5.40 \mathrm{TU}$ in rainy period, respectively. These $\delta^{3} \mathrm{H}$ values of waters could be represented that this waters are deep aquifer waters and slow circulation. The determination of the natural radioactivity in groundwater is important in terms of human health. The gross alpha and gross beta radioactivity concentrations of waters varied between 29-162 $\mathrm{mBq} \mathrm{L} \mathrm{L}^{-1}$ and $70-330 \mathrm{mBq} \mathrm{L}^{-1}$, respectively. The results have shown that gross $\alpha$ and $\beta$ radioactivity concentrations in drinking waters in the basin are relatively low and suitable the World Health Organization regulations for drinking water.
\end{abstract}

Keywords: Drinking water, Stable isotope, Natural radioactivity, Sandıklı basin

\section{Introduction}

The corresponding development and management of the groundwater resources in the study area require detailed and reliable information on the origin and the natural recharge rate of groundwater [1].The environment isotopes of oxygen $\delta^{180}$ and hydrogen $\delta^{2} \mathrm{H}$ are excellent tracers for determining the origin of groundwater and widely used in studying the natural water circulation and groundwater movement [2].The isotopic signatures of oxygen and hydrogen are influenced by atmospheric and surface processes encountered during the groundwater recharge [3]. In addition to the stable isotopes in groundwater studies as tracers of groundwater provenance and age, isotopes are also used to study the quality of groundwater, geochemical evaluation, water-rock interaction, the origin of salinity, recharge processes and contaminant processes. On the other hand, in water cycle studies the stable isotopes of hydrogen $\left(\delta^{2} \mathrm{H}\right)$ and oxygen $\left(\delta^{18} \mathrm{O}\right)$ in $\mathrm{H}_{2} \mathrm{O}$ have long been used as naturally occurring tracers to asses rainfall importance, to track the source and flux of water to and from rivers and lakes in watersheds, and to evaluate the origin and
Öz

Sandıklı havzası Türkiye'nin güneybatısında yeralmaktadır. Bu makalede, Sandıklı havzasındaki akifer sisteminin beslenimini anlamak için yeraltısuyu duraylı izotop analizleri değerlendirilmiştir. Bu amaçla, havzada 2009-2010 yıllarında iki dönem boyunca yeraltısular örnekleri toplanmıș ve duraylı izotop ile doğal radyoaktivite analizleri yapılmıştır. Bölgedeki yeraltısularının $\delta^{18} \mathrm{O}$ ve $\delta^{2} \mathrm{H}$ içerikleri sırasıyla $\%$-8.08 ile \%o-10.77 ve \%o-52.44 ile \%o-69.53 arasındadır. Durayl izotop verileri genellikle Küresel Meteorik Su Doğrusu üzerindedir ve sular meteorik kökenlidir. Yeraltısularının trityum içeriği kurak dönemde 0.00-4.20 TU ve yağışlı dönemde 0.30-5.40 TU arasındadır. Trityum içeriğine göre yeraltısuları derin akifer ve yavaș dolașımı göstermektedir. Yeraltısularındaki doğal radyoaktivitenin belirlenmesi insan sağlığı açısından önemlidir. Suların toplam alfa ve beta radyoaktivite konsantrasyonları $29-162 \mathrm{mBq} \mathrm{L}^{-1}$ ve $70-330 \mathrm{mBq} \mathrm{L}^{-1}$ arasında değişmektedir. Havzadaki içme sularında toplam $\alpha$ ve $\beta$ radyoaktivite konsantrasyonları nispeten düşük ve Dünya Sağlık Örgütü'nün içme suyu kriterlerine uygundur.

Anahtar kelimeler: İçme suyu, Duraylı izotop, Doğal radyoaktivite Sandıklı havzası

age of groundwater resources [4],[5]. Many researches focus on the assessment of isotopic geochemistry in natural water resources [6]-[14]. Also, many studies were performed on natural radioactivity (gross alpha and gross beta) in groundwater [15]-[21].

The groundwater is widely used for drinking, domestic and irrigation purposes in the Sandıklı basin. The basin is selected as the investigation area because groundwater is the major source for using as irrigation and drinking water in the basin. For this reason, there are many studies in this region [22]-[28]. The study's main objective was to identify isotopic compositions and radioactivity parameters of groundwater in the Sandıklı basin, was investigated seasonally to determine the relationship between major aquifers.

\section{Material and method}

\subsection{Study area}

The Sandıklı Basin is located in the Aegean region of Turkey at $29^{\circ} 50^{\prime}-30^{\circ} 30^{\prime} \mathrm{E}, 38^{\circ} 15^{\prime}-38^{\circ} 45^{\prime} \mathrm{N}$ and covers an area of $1556 \mathrm{~km}^{2}$. The basin is formed a combination of Sandıklı 
Kuruçay plain and Küçük Sincanlı plain. The basin has semi-closed properties due to Kestel creek. There is also the Hudai geothermal area in the basin (Figure 1).

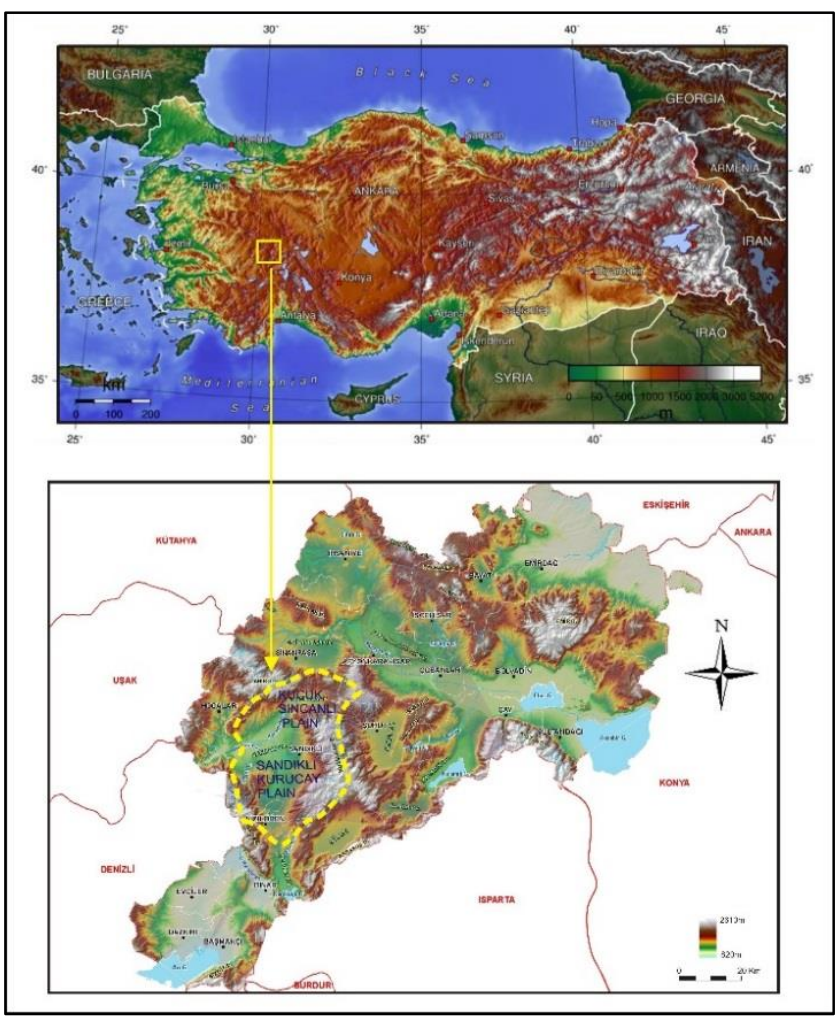

Figure 1: Location map of investigation area.

\subsection{Sampling and analytical methods}

A total of 10 water samples were collected periodically in two terms for dry and rainy periods during the water year of $2009 / 2010$. Water samples were taken from the drilling wells and technical parameters (well depth, groundwater depth and yield) of the wells were presented in Table 1. All sample locations (Alamescit (1), Sandıklı (2), Gökçealan (3), Sorkun (4) and Serban (5)) were situated with Global Positioning System (GPS) equipment and prepared location map (Figure 2). Physical parameters of the water samples such as $\mathrm{pH}$, temperature $\left(\mathrm{T} ;{ }^{\circ} \mathrm{C}\right)$ and electrical conductivity $(\mathrm{EC} ; \mu \mathrm{S} / \mathrm{cm})$ were measured in situ with YSI Professional Plus handheld multiparameter instrument that were calibrated with standard solutions before use. Samples were collected in $100 \mathrm{ml}$ clean polyethylene bottles and dispatched for analysis to the laboratory in an ice-filled box.

Major elements such as cations $\left(\mathrm{Na}^{+}, \mathrm{K}^{+}, \mathrm{Ca}^{2+}, \mathrm{Mg}^{2+}\right)$ and anions $\left(\mathrm{Cl}-\mathrm{SO}_{4}^{2-}, \mathrm{HCO}_{3}-, \mathrm{CO}_{3}{ }^{2-}\right)$ were measured taking into consideration standards of analyses (TS 4530, TS 4474, TS 3790, TS 4164, EN ISO 9297, TS 5095) in the laboratory of the State Hydraulic Works (SHW). Results of chemical and physical analysis were presented seasonally in Table 2 and 3 . Stable isotope techniques were used to interpret recharge mechanisms of the aquifer in the basin. Stable isotope samples were taken in 1-liter polyethylene bottles. Water samples for oxygen $\left(\delta^{18} \mathrm{O}\right)$, deuterium $\left(\delta^{2} \mathrm{H}\right)$, radioactive isotopes of hydrogen (tritium- $\delta^{3} \mathrm{H}$ ), isotopic analysis and gross alpha $(\alpha)$, gross beta $(\beta)$ radioactive analysis were analyzed by the Ankara Technical Research and Quality Control Department of Isotope Laboratory and Director in the SHW. Results of isotopic, gross alpha-beta and radioactive analysis were presented seasonally in Table 2 and 3. $\delta^{18} 0$ and $\delta^{2} \mathrm{H}$ from isotopic compositions of the samples were determined using International Atomic Energy Agency (IAEA)-Equilibration method. Also, $\delta{ }^{3} \mathrm{H}$ was determined using IAEA-Liquid Siltation Counting (LSC) Technique. The isotopes results are expressed with respect to the Global Meteoric Water (GMW). Tritium concentrations are expressed as absolute concentrations, using tritium units (TU). The tritium units is $1 \mathrm{TU}=0.1183 \mathrm{~Bq} / \mathrm{L}$. The precision of measurements is \pm 1 TU. Determination of natural radioactivity in drinking water samples were used EPA 900.0 method.

\section{Results and discussion}

\subsection{Geology}

Paleozoic, Mesozoic and Cenozoic aged rock outcropped in the investigation area. Sedimentary and volcanic rocks are located on the metamorphic base. Quaternary units are covered all of the units as discordant. Precambrian aged metamorphic rocks are composed of quartz, sericite schist, albite, quartzite, calcschist, phyllite and metabasalt and the metamorphic rocks are form basis of the investigation area. Mesozoic aged limestones and Miocene aged volcanic rocks in the study area show a very wide spread. Volcanic rocks which is composed of andesite, trachy andesite, basalt, tuff, tuffite and agglomerate. Pliocene and Quaternary aged units are current deposits of study area and covers all units unconformably [22],[29],[30], (Figure 2).

\subsection{Hydrogeology}

Pliocene and Quaternary aged units have similar lithological features in the study area. So, these units were characterized porous aquifer system in the investigation area.

The aquifer system is composed of sand, gravel, clay and silt levels. The thickness of the aquifer system ranges from approximately $200-300 \mathrm{~m}$ and it has a productive aquifer character. Also, Mesozoic aged unit which is consists of limestones are karstic aquifer [22]. The most important surface flow of the study area is Kestel creek (Figure 2). The groundwater flow direction is towards NE in south of the basin, towards north in west of the basin and towards Kestel creek in north of the basin [26]. Water samples were taken from the wells on the porous aquifer. The technical parameters of the wells are depth from 160 to $202 \mathrm{~m}$, groundwater depth ranges from 4.85 to 83.65 and yield ranges from 13.56 to $51.10 \mathrm{l} / \mathrm{s}$ (Table 1).

\subsection{Hydrochemistry}

The physical parameters of water samples were measured insitu for two periods (dry and rainy) and the results (pH, EC and $\mathrm{T}$ ) shown in Table 2, 3. The electrical conductivity (EC) content of groundwater samples ranges from 124 to $397 \mu \mathrm{s} / \mathrm{cm}$, temperature from 12.39 to $22.58{ }^{\circ} \mathrm{C}$ and $\mathrm{pH}$ from 7.16 to 8.68 , respectively (Table 2,3 ). The major constituent chemical composition results are summarized in a Piper [31] plot (Figure 3).

Four different water facies are determined in the study area. These facies are " $\mathrm{CaMgHCO}_{3}, \mathrm{CaHCO}_{3}, \mathrm{CaMgHCO}_{3} \mathrm{SO}_{4}$ and $\mathrm{CaMgSO}_{4} \mathrm{HCO}_{3}$ " (Table 2, 3). The $\mathrm{CaMgHCO}_{3}$ type water may correspond to the upper zone [34]. This facies is also the most abundant type of water in the basin. The order of abundance of anions and cations in the water from both periods is: $\mathrm{Ca}^{+2}>\mathrm{Mg}^{+2}>\mathrm{Na}^{+}>\mathrm{K}^{+}$and $\mathrm{HCO}_{3}>\mathrm{SO}_{4}^{-2}>\mathrm{Cl}>\mathrm{CO}_{3}{ }^{-2}$. Calcium is the dominant cation found in the groundwater of the study area. Its 
concentration is generally higher than $2.00 \mathrm{meq} / \mathrm{L}$. Bicarbonate dominates the anionic components of the groundwater, with a mean value of $2.59 \mathrm{meq} / \mathrm{L}$ (Table 2). The Sandıklı (2) water samples $\left(\mathrm{CaMgHCO}_{3} \mathrm{SO}_{4}\right)$ was taken from the well near the
Hudai geothermal field. Therefore, the water samples (2) have the highest temperature values among all groundwaters samples and the cation are dominated $\mathrm{SO}_{4}^{2-}$. So, the sample was affected from the thermal water [27].

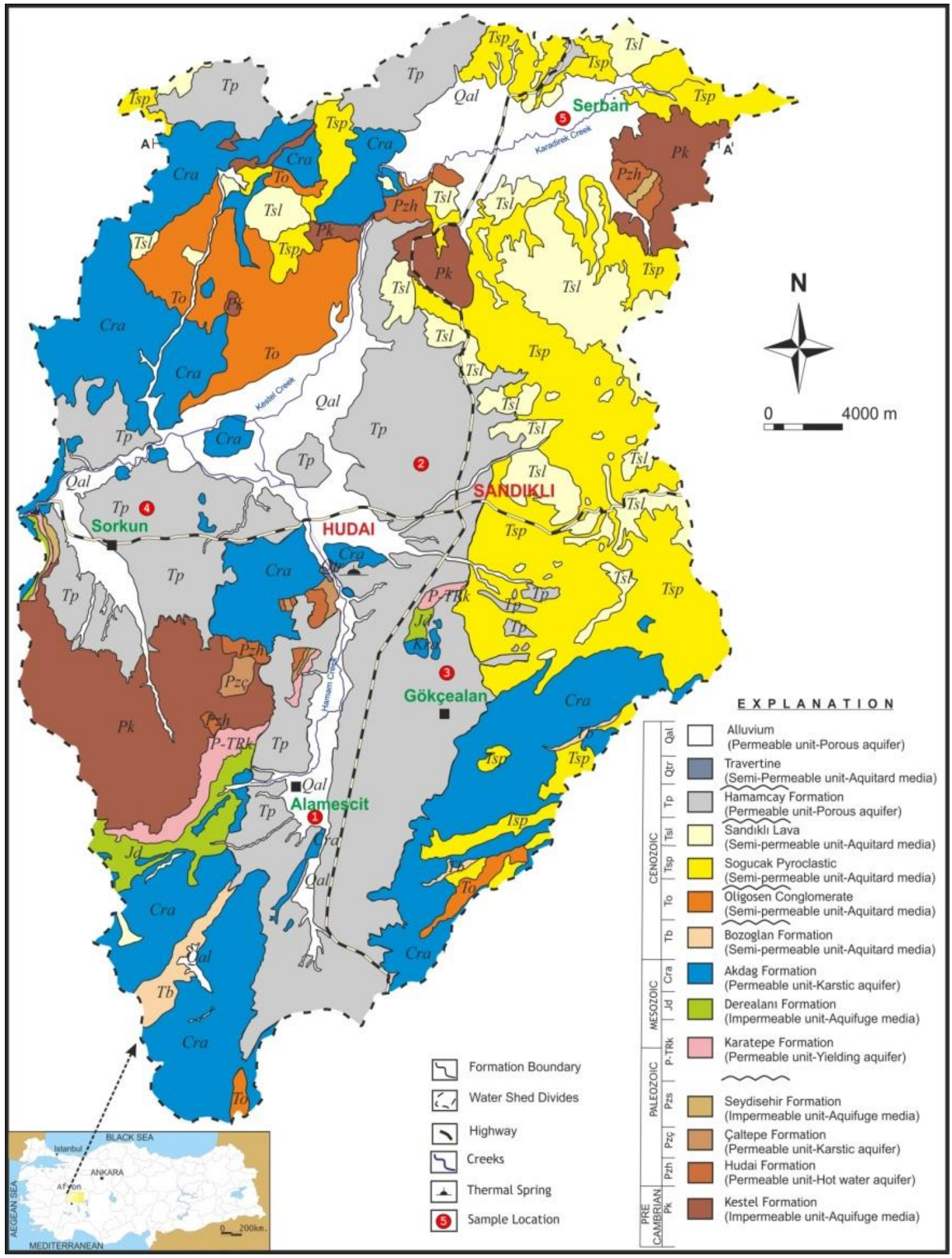

Figure 2: Geological and hydrogeological map of investigation area (were revised [22]). 
Table 1: Technical parameters of wells in the study area [22].

\begin{tabular}{|c|c|c|c|c|c|c|}
\hline Sample Number & & 1 & 2 & 3 & 4 & 5 \\
\hline Area & & Alamescit & Sandıklı & Gökçealan & Sorkun & Serban \\
\hline Well depth & $(\mathrm{m})$ & 202 & 160 & 202 & 190 & 200 \\
\hline Groundwater depth & $(\mathrm{m})$ & 52.24 & 7.88 & 83.65 & 18.04 & 4.85 \\
\hline Yield & $(\mathrm{l} / \mathrm{s})$ & 20.69 & 22.14 & 18.40 & 51.10 & 13.56 \\
\hline \multicolumn{7}{|c|}{ Table 2: Analyses results August-2009 (Dry Period). } \\
\hline Sample Number & & 1 & 2 & 3 & 4 & 5 \\
\hline Area & & Alamescit & Sandıklı & Gökçealan & Sorkun & Serban \\
\hline \multicolumn{7}{|l|}{ Physical parameters } \\
\hline \multirow{3}{*}{ Coordinate } & $\mathrm{X}(\mathrm{E})$ & 252150 & 259781 & 259569 & 242921 & 269105 \\
\hline & $\mathrm{Y}(\mathrm{N})$ & 4247651 & 4259598 & 4250516 & 4259634 & 4281028 \\
\hline & $\mathrm{Z}(\mathrm{m})$ & 1033 & 1060 & 1096 & 1021 & 1234 \\
\hline $\mathrm{pH}$ & & 7.19 & 7.78 & 7.9 & 8.34 & 7.16 \\
\hline EC & $(\mu \mathrm{S} / \mathrm{cm})$ & 324 & 363 & 195 & 237 & 124 \\
\hline $\mathrm{T}$ & $\left({ }^{\circ} \mathrm{C}\right)$ & 16.48 & 22.58 & 14.87 & 19.81 & 16.15 \\
\hline \multicolumn{7}{|c|}{ Chemical parameters } \\
\hline $\mathrm{Na}^{+}$ & (meq/L) & 0.64 & 0.77 & 0.24 & 0.17 & 0.42 \\
\hline $\mathrm{K}^{+}$ & (meq/L) & 0.04 & 0.1 & 0.17 & 0.06 & 0.11 \\
\hline $\mathrm{Ca}^{2+}$ & (meq/L) & 3.5 & 2.21 & 2.04 & 1.96 & 0.8 \\
\hline $\mathrm{Mg}^{2+}$ & (meq/L) & 0.87 & 1.72 & 0.44 & 1.12 & 0.78 \\
\hline $\mathrm{Cl}^{-}$ & (meq/L) & 0.23 & 0.55 & 0.20 & 0.12 & 0.25 \\
\hline $\mathrm{SO}_{4}^{2-}$ & $(\mathrm{meq} / \mathrm{L})$ & 0.48 & 1.71 & 0.04 & 0.06 & 0.33 \\
\hline $\mathrm{HCO}_{3}^{-}$ & (meq/L) & 3.52 & 2.02 & 2.17 & 2.59 & 1.21 \\
\hline Water Type & & $\mathrm{CaHCO}_{3}$ & $\mathrm{CaMgHCO}_{3} \mathrm{SO}_{4}$ & $\mathrm{CaHCO}_{3}$ & $\mathrm{CaMgHCO}_{3}$ & $\mathrm{CaMgHCO}_{3}$ \\
\hline \multicolumn{7}{|c|}{ Isotopic composition ( ${ }^{*} \mathrm{~d}$-excess $\left.=\delta^{2} \mathrm{H}-\mathbf{8}^{18} 0[32]\right)$} \\
\hline$\delta^{18} 0$ & $(\%)$ & -9.25 & -9.34 & -9 & -9.67 & -10.77 \\
\hline$\delta^{2} \mathrm{H}$ & $(\%)$ & -57.85 & -60.35 & -59.55 & -59.52 & -68.06 \\
\hline$\delta^{3} \mathrm{H}$ & (TU) & 0.9 & 0 & 0 & 4.2 & 0.45 \\
\hline$\delta^{3} \mathrm{H}$ & $\left(\mathrm{Bq} \mathrm{L} \mathrm{L}^{-1}\right)$ & 0.11 & 0 & 0 & 0.5 & 0.05 \\
\hline d-excess ${ }^{*}$ & $(\%)$ & 16.15 & 14.37 & 12.45 & 17.84 & 18.1 \\
\hline \multicolumn{7}{|c|}{ Gross alfa/beta activities (Limit values; $\alpha: 500 \mathrm{mBq} \mathrm{L}^{-1}, \beta: 1000 \mathrm{mBq} \mathrm{L}^{-1}[33]$ ) } \\
\hline$\alpha$ & $\left(\mathrm{mBq} \mathrm{L}^{-1}\right)$ & 90 & 162 & 86 & 90 & 57 \\
\hline$\beta$ & $\left(\mathrm{mBq} \mathrm{L}^{-1}\right)$ & 110 & 190 & 280 & 80 & 140 \\
\hline
\end{tabular}

Table 3: Analyses results April-2010 (Wet Period).

\begin{tabular}{|c|c|c|c|c|c|c|}
\hline \multicolumn{2}{|c|}{ Sample Number } & 1 & 2 & 3 & 4 & 5 \\
\hline \multicolumn{2}{|c|}{ Area } & Alamescit & Sandıklı & Gökçealan & Sorkun & Serban \\
\hline \multicolumn{7}{|c|}{ Physical parameters } \\
\hline \multirow{3}{*}{ Coordinate } & $X(E)$ & 252150 & 259781 & 259569 & 242921 & 269105 \\
\hline & $Y(N)$ & 4247651 & 4259598 & 4250516 & 4259634 & 4281028 \\
\hline & $\mathrm{Z}(\mathrm{m})$ & 1033 & 1060 & 1096 & 1021 & 1234 \\
\hline \multicolumn{2}{|l|}{$\mathrm{pH}$} & 7.78 & 8.11 & 8.68 & 8.51 & 8.47 \\
\hline EC & $(\mu \mathrm{S} / \mathrm{cm})$ & 397 & 375 & 227 & 135 & 134 \\
\hline \multicolumn{2}{|r|}{$\left({ }^{\circ} \mathrm{C}\right)$} & 12.39 & 20.01 & 13.03 & 12.79 & 13.53 \\
\hline \multicolumn{7}{|c|}{ Chemical parameters } \\
\hline \multicolumn{2}{|c|}{$\mathrm{Na}^{+} \quad(\mathrm{meq} / \mathrm{L})$} & 0.4 & 0.75 & 0.19 & 0.17 & 0.4 \\
\hline $\mathrm{K}^{+}$ & (meq/L) & 0.06 & 0.21 & 0.14 & 0.04 & 0.06 \\
\hline $\mathrm{Ca}^{2+}$ & (meq/L) & 5.47 & 2.28 & 3.07 & 1.38 & 5.47 \\
\hline $\mathrm{Mg}^{2+}$ & (meq/L) & 1.02 & 1.51 & 0.39 & 0.49 & 1.02 \\
\hline $\mathrm{Cl}^{-}$ & (meq/L) & 0.30 & 0.65 & 0.2 & 0.12 & 0.30 \\
\hline $\mathrm{SO}_{4}^{2-}$ & (meq/L) & 0.88 & 2.29 & 0.19 & 0.27 & 0.88 \\
\hline $\mathrm{HCO}_{3}^{-}$ & (meq/L) & 5.74 & 1.7 & 3.44 & 1.8 & 5.74 \\
\hline Water Type & & $\mathrm{CaHCO}_{3}$ & $\mathrm{CaMgHCO}_{3} \mathrm{SO}_{4}$ & $\mathrm{CaHCO}_{3}$ & $\mathrm{CaMgHCO}_{3}$ & $\mathrm{CaMgHCO}_{3}$ \\
\hline \multicolumn{7}{|c|}{ Isotopic composition ( ${ }^{*} \mathrm{~d}-\mathrm{excess}=\boldsymbol{\delta}^{2} \mathrm{H}-\mathbf{8 \delta}^{18} \mathrm{O}[32]$ ) } \\
\hline$\delta^{18} \mathrm{O}$ & $(\% 0)$ & -8.08 & -8.58 & -8.24 & -8.25 & -10.27 \\
\hline$\delta^{2} \mathrm{H}$ & $(\%)$ & -54.25 & -61.08 & -57.62 & -52.44 & -69.53 \\
\hline$\delta^{3} \mathrm{H}$ & (TU) & 4 & 0.3 & 5.4 & 2.2 & 0.5 \\
\hline$\delta^{3} \mathrm{H}$ & $\left(\mathrm{Bq} \mathrm{L}^{-1}\right)$ & 0.47 & 0.04 & 0.64 & 0.26 & 0.05 \\
\hline d-excess ${ }^{*}$ & $(\% 0)$ & 10.39 & 7.56 & 8.3 & 13.56 & 12.63 \\
\hline \multicolumn{7}{|c|}{ Gross alfa/beta activities (Limit values; $\alpha: 500 \mathrm{mBq} \mathrm{L}^{-1}, \beta: 1000 \mathrm{mBq} \mathrm{L}^{-1}[33]$ ) } \\
\hline$\alpha$ & $\left(\mathrm{mBq} \mathrm{L}^{-1}\right)$ & 79 & 159 & 32 & 31 & 29 \\
\hline$\beta$ & $\left(\mathrm{mBq} \mathrm{L}^{-1}\right)$ & 70 & 330 & 130 & 100 & 130 \\
\hline
\end{tabular}




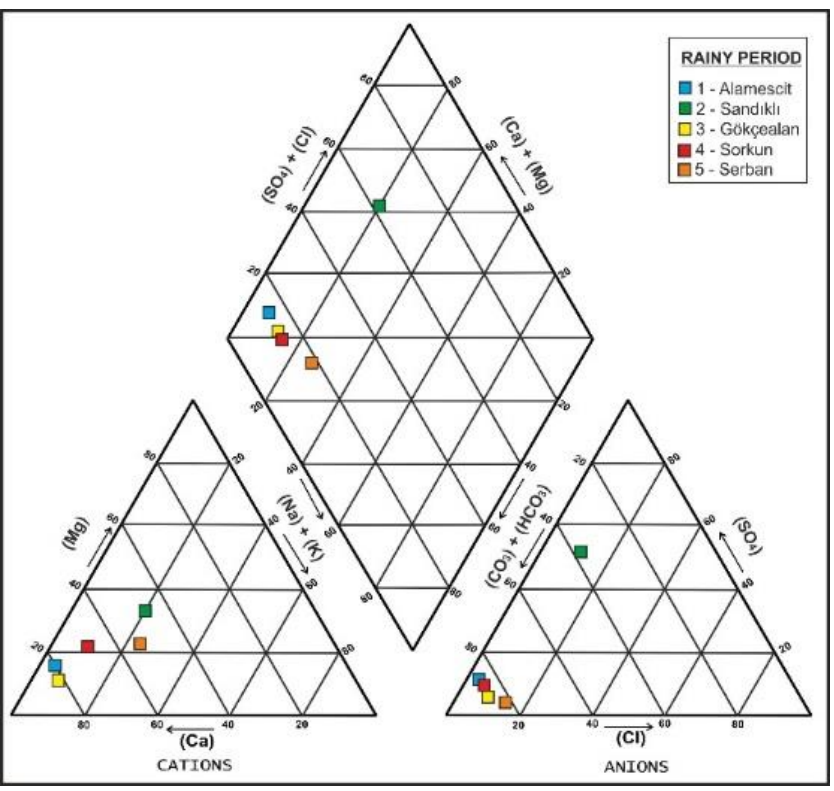

Figure 3: Piper diagram.

\subsection{Stable Isotope (hydrogen and oxygen) Composition in Groundwater}

The environmental isotopes of oxygen $\left(\delta^{18} 0\right)$, hydrogen $\left(\delta^{3} \mathrm{H}\right)$ and deuterium $\left(\delta^{2} \mathrm{H}\right)$ are excellent tracers for determining the origin of groundwater and widely used in studying the natural water circulation and groundwater movement.

The stable isotope analyses were made in dry and rainy period in the Sandıklı basin. Tables 2 and 3 contain data of isotopic compositions of groundwater. Isotope values of groundwaters showed that the seasonally variation. The isotopes composition in groundwater samples range from $-9.00 \%$ o to $-10.77 \%$ o $\delta^{18} 0$ (dry period) and from $-8.08 \% 0$ to $-10.27 \% 0 \delta^{18} 0$ (rainy period), respectively. The $\delta^{2} \mathrm{H}$ values in both periods range from$57.85 \%$ to $-68.06 \%$ and range from $-52.44 \%$ to-69.53\%, respectively (Table 2,3 ). The average values of $\delta^{18} \mathrm{O}$ and $\delta^{2} \mathrm{H}$ in groundwater are -9.1 and $-60.0 \%$, respectively.

The origins and recharge conditions of waters were determined using the $\delta^{18} 0-\delta^{2} \mathrm{H}$ graphic. The relationship between the $\delta^{18} 0$ and $\delta^{2} \mathrm{H}$ values in water samples were plotted in Figure 4. In this graph is defined as follows:

-The Global Meteoric Water Line (GMWL), [35]

$\left(\delta^{2} \mathrm{H}=8 \delta^{18} \mathrm{O}+10\right)$

-The meteoric water line of Antalya in Turkey (AMWL), [36]

$\left(\delta^{2} \mathrm{H}=8 \delta^{18} \mathrm{O}+16.37\right)$

-The meteoric water line of Koçbeyli (Isparta) in Turkey (KMWL), [36]

$\left(\delta^{2} \mathrm{H}=8 \delta^{18} 0+12.16\right)$

Isotopic composition of groundwaters within Sandıklı region compared with Global Meteoric Water Line (GMWL). The values plotted close to the GMWL with d-excess value of $10 \%$, the AMWL with d-excess value of $16.37 \%$ and the KMWL with $\mathrm{d}$-excess value of $12.16 \%$. The majority of stable isotope values in groundwater samples plot above and to the left of the GMWL, the KMWL and the AMWL (Figure 4). The close proximity to the meteoric water lines in this graph determines that the waters were of meteoric origin. The samples also plotted in the more negative values in the graph, which is appropriate for waters can be recharged at colder temperatures. But, sample 2 has the more negative values due to the high temperature in the dry and rainy period. This situation is also supported by the [27] According to the GMLW, evaporation can be in sample 1,4 and 5 , condensation can be sample 3 and water-rock interaction can be sample 2 .

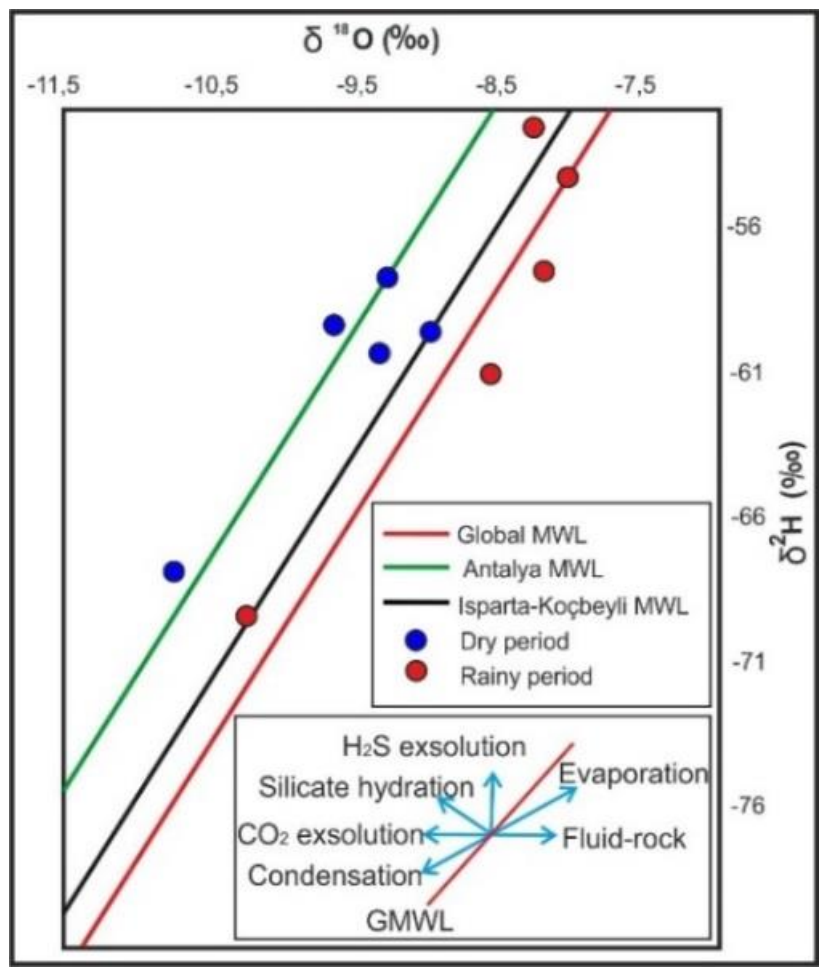

Figure 4: Plot of $\delta^{2} \mathrm{H}$ and $\delta^{18} \mathrm{O}$ for groundwater samples.

\subsection{Tritium in groundwater}

Tritium is produced in the upper atmosphere. Presence of tritium in groundwater immediately indicates that the aquifer is being recharged with water that originated within the last 40-50 years [37]. Tritium concentrations in groundwater may be used as indicators of groundwater age by comparison with historical records of elevated tritium levels in precipitation, which resulted from atmospheric thermonuclear testing in the early 1950s to late 1970s [38], [39]. Tritium is a short-lived isotope of hydrogen with a half-life of 12.43 years. Activity of geogenic ${ }^{3} \mathrm{H}$ in most groundwater is negligible, thus measurable ${ }^{3} \mathrm{H}$ in groundwater samples virtually always signifies modern recharge [4].

Relative residence time of groundwater was estimated qualitatively and semi-quantitatively in tritium units (TU), based on the concentration of tritium [4], as follows Table 4.

Table 4: Qualitative dating of groundwaters in continental regions [4].

\begin{tabular}{|c|c|}
\hline $\begin{array}{l}\text { Tritium Content } \\
\text { (TU) }\end{array}$ & $\begin{array}{c}\text { Age/ } \\
\text { Period of Groundwater }\end{array}$ \\
\hline$<0.8$ & Sub-modern (recharged prior to 1952) \\
\hline $0.8-4$ & Mixture of sub-modern and modern \\
\hline $5-15$ & Modern $(<5-10$ years $)$ \\
\hline $15-30$ & Some bomb tritium present \\
\hline$>30$ & Recharged in $1960 \mathrm{~s}-1970 \mathrm{~s}$ \\
\hline$>50$ & Recharged in $1960 \mathrm{~s}$ \\
\hline
\end{tabular}


Tritium concentrations in groundwater samples are presented in Tables 2 and 3; for convenience, concentrations are presented in both $\mathrm{Bq} \mathrm{L}^{-1}$ and TU. The tritium concentrations in groundwater samples are very low and ranging from 0.00 to-4.20 TU (dry period) and from 0.30 to $5.40 \mathrm{TU}$ (rainy period), respectively (Table 2,3 ). The tritium values in water samples (dry period; 2,3 and 5, rainy period; 2 and 5 samples) are less than $1 \mathrm{TU}$ in the both period and indicating that the samples were recharged after 1952, the "sub-modern" category presented by [4]. Sample 1 (dry and rainy period) and 4 (rainy period) of the tritium values are indicated from 0.8 to 4TU and the samples are identified "mixture of sub-modern and modern" waters. The tritium values of sample 3 in rainy period are "modern" means of age 5-10 years. The heavy metal (Fe concentration) increase in the Gökçealan (3) region is originated from anthropogenic effects as related to agricultural activities [27]. Modern groundwater generally is more susceptible to contamination than old because of the many anthropogenic contaminants introduced during the $20^{\text {th }}$ century [40].

A plot of tritium versus $\delta^{18} 0$ in groundwater is shown Figure 5. Sample 3 and 4 (dry period) and sample 1 (rainy period) are have shallow and fast circulation, and recharged from current precipitation. The other samples are represented deep and slow circulation (Figure 5).

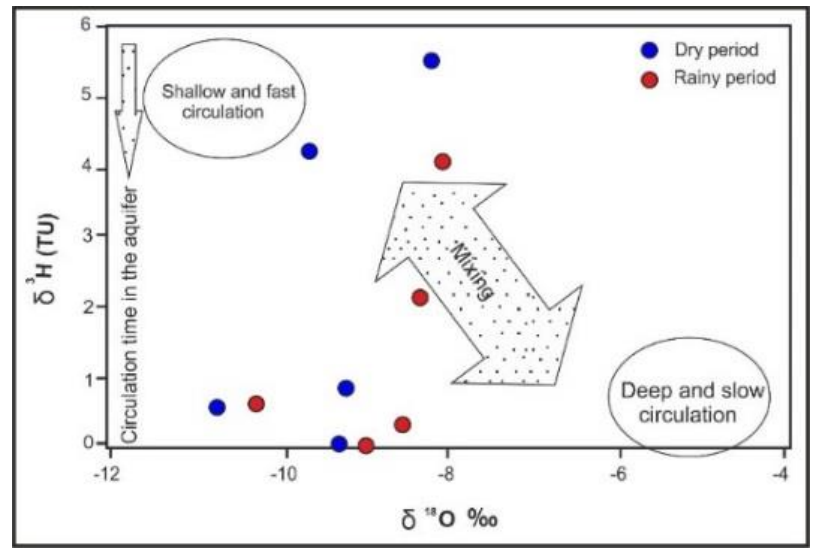

Figure 5: Tritium versus oxygen isotope values of groundwater samples.

The tritium contents for groundwater in basin show little seasonal variation. The $\mathrm{EC}-{ }^{3} \mathrm{H}$ graphic show that the circulation period of waters in the aquifers and relationship with rocks of waters (Figure 6a). Generally, water samples have low temperature, tritium content $>1 \mathrm{TU}$, low electrical conductivity, and low $\mathrm{Cl}^{-}$values. However, sample 2 have low tritium, high temperature, high electrical conductivity, and high $\mathrm{Cl}^{-}$values in the region show that this groundwater has deep circulation and long residence time (Figure 6b, 6c).The reason for this, the sample was affected from the Hudai geothermal region.

\subsection{The d-excess values in groundwater}

Another piece of evidence for the origin of recharge of the investigated area is gained from the value of the deuterium excess (d-excess). Regionally, d-excess values vary due to differences in meteorological conditions at the source region of the vapour mass relative to that at which the precipitation is derived [41]. The d-excess values are defined by the following equation (1), [32].

$$
d-\text { excess }=\delta^{2} H-8 \delta^{18} O
$$

The d-excess values for the groundwater samples in the investigation area ranged from 12.45 to $18.1 \%$ and from 7.56 to $13.56 \%$ for dry and rainy periods, respectively (Table 2,3 ).
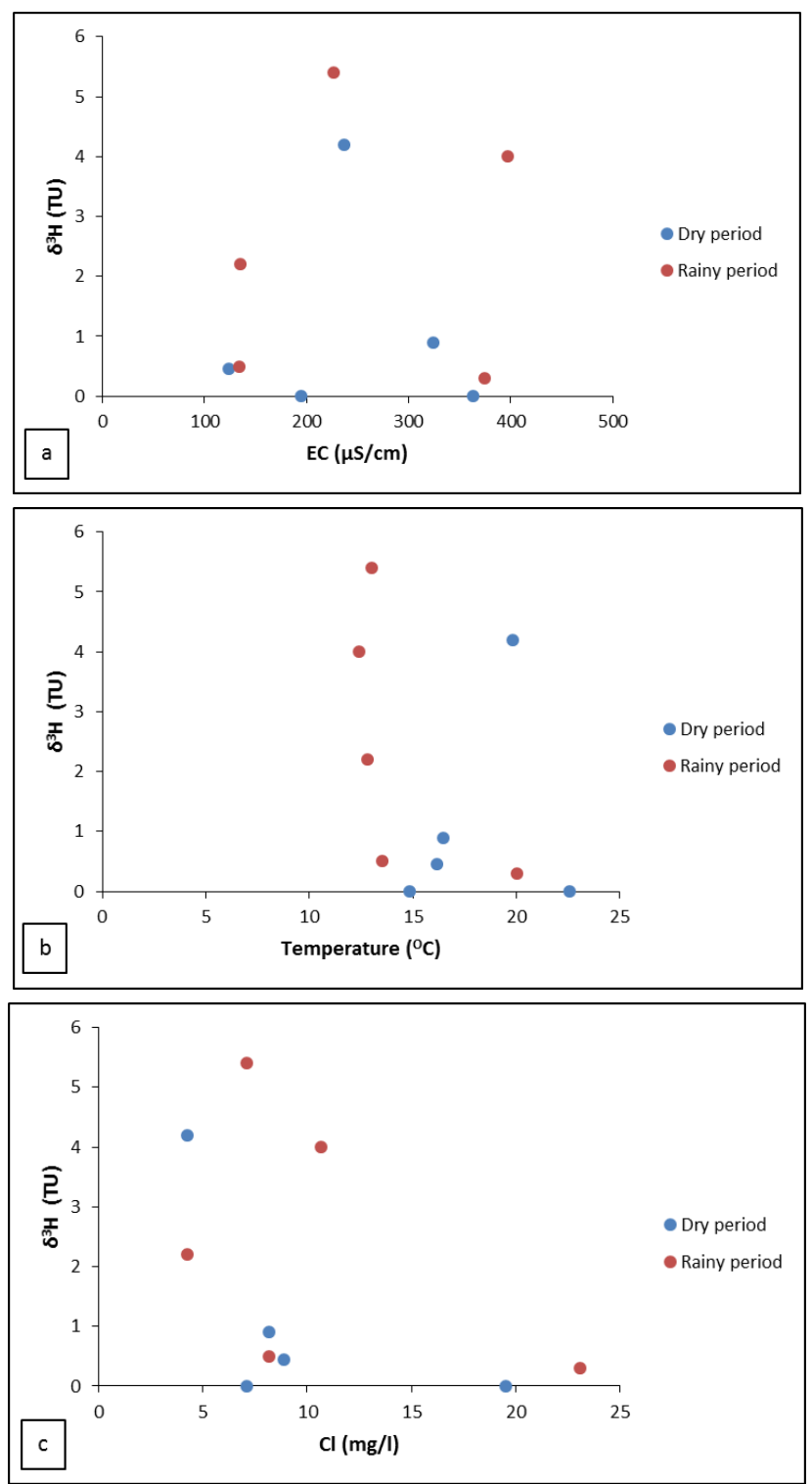

Figure 6: (a): $\delta^{3} \mathrm{H}(\mathrm{TU})$-Electrical conductivity $(\mu \mathrm{S} / \mathrm{cm})$; (b): $\delta^{3} \mathrm{H}(\mathrm{TU})$-Temperature $\left({ }^{\circ} \mathrm{C}\right) ;(\mathrm{c}): \delta^{3} \mathrm{H}$ (TU)-Chlorine $(\mathrm{mg} / \mathrm{L})$ relation for groundwater samples.

The samples represent groundwater affected by evaporation which is also reflected in the higher value of $\delta^{18} 0$ with correspondingly lower d-excess. During the process of evaporation, the residual water not only enriches in heavier isotopes but also shows progressively lower d-excess due to relatively more enrichment of $\delta^{18} 0$ [3]. The d-excess of the groundwaters in this region for both term vary between $7 \% 0$ and 18\%, again reflecting inheritance from precipitation (Figure 7a). The groundwater with d-excess $>5 \%$ and lower $\delta^{18} 0<-5 \%$ are representative of low evaporation and higher permeability [3],[21]. A cross plot of $\delta^{18} 0$ versus d-excess indicates that low evaporative and rainfall the primary source of recharge (Figure 7a).

The plot of the EC and the d-excess values presented Figure $7 \mathrm{~b}$. The groundwater in the basin whose d-excess values (from 
12.45 to $18.1 \%$ and from 7.56 to $13.56 \%$ ) has a tendency for decreasing with increasing EC values (from 124 to $363 \mu \mathrm{s} / \mathrm{cm}$ and from 134 to $397 \mu \mathrm{s} / \mathrm{cm}$ ) in dry and rainy periods (Table 2, 3). Also, the other groundwater of rainy period is shown the same properties. This indicates that evaporation does not appear to influence salinization.Stable isotopes in conjunction with $\mathrm{Cl}^{-}$have been used to assess the relative influence of evaporation and rock-water interaction [42]. Figure 7c shows a plot of d-excess values against $\mathrm{Cl}^{-}$in grounwater. Data for all groundwater samples except sample 2 (high $\mathrm{Cl}^{-}$value) are plotted within positive correlation.
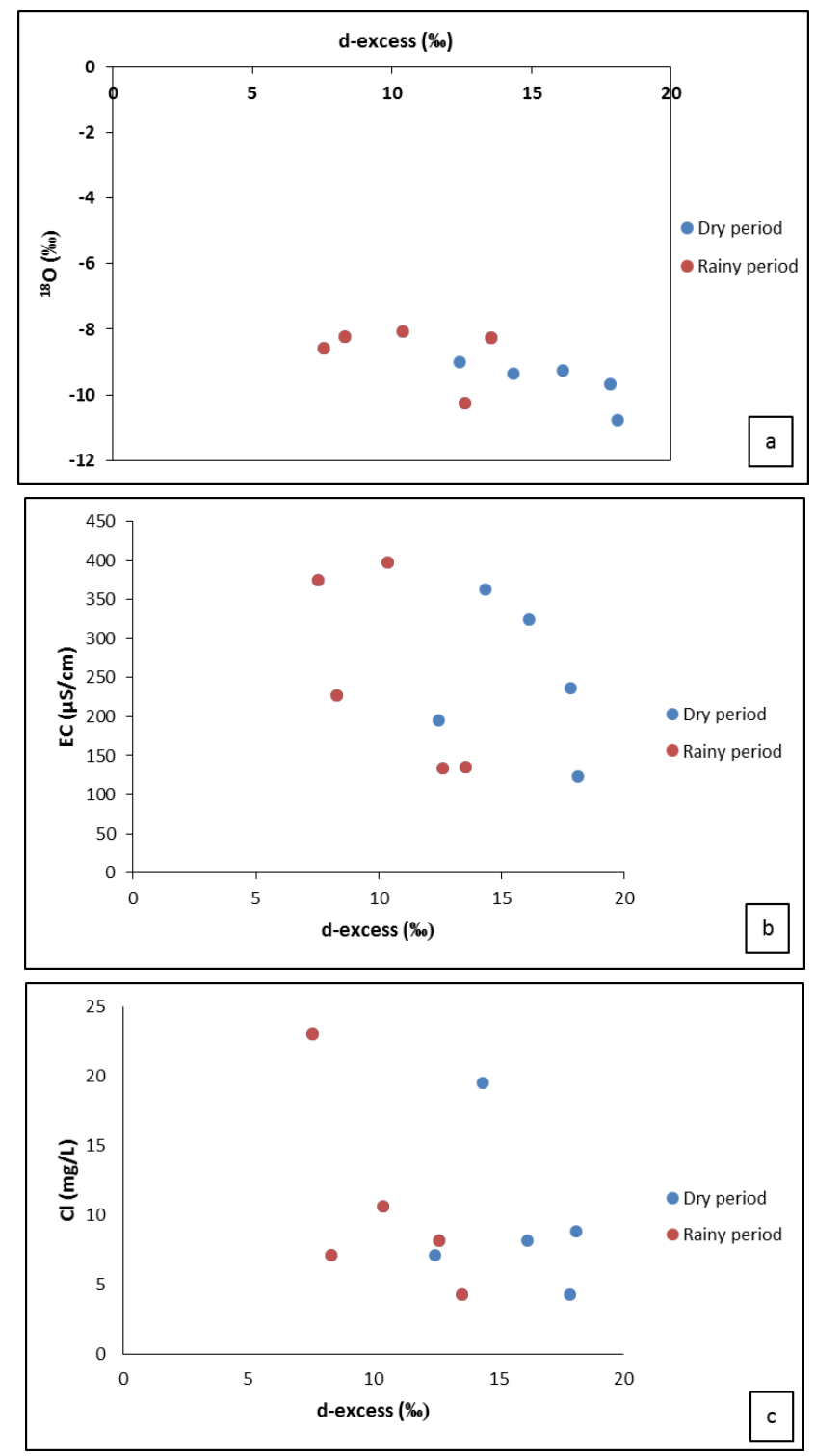

Figure 7: (a): d-excess (\%o)- $\delta^{180}(\% 0)$; (b): d-excess (\%o)-EC

$(\mu \mathrm{S} / \mathrm{cm}),(\mathrm{c})$ : d-excess (\%o)-Cl- $(\mathrm{mg} / \mathrm{L})$ relation for groundwater sample.

\subsection{Natural radioactivity}

Gross alpha and beta activities are very useful parameters for the preliminary screening of waters [43]. Drinking water may contain radioactivity that could present a risk to human health [44]. The gross $\alpha$ and $\beta$ activity can be used for detecting changes in the radiological characteristics of the drinking water source [33]. In general, the screening levels or limit values of the gross $\alpha$ and $\beta$ have been recommended as $500 \mathrm{mBq} \mathrm{L}^{-1}$ and $1000 \mathrm{mBq} \mathrm{L}{ }^{-1}$ respectively. In Table 2 and 3 measured gross alpha $(\alpha)$ and beta $(\beta)$ concentrations are summarized. The values of the activity concentrations of the gross $\alpha$ and $\beta$ measured in the water samples ranged from 29 to $162 \mathrm{mBq} \mathrm{L}^{-1}$ with a mean of $81.5 \mathrm{mBq} \mathrm{L}^{-1}$ and $70-330 \mathrm{mBq} \mathrm{L}^{-1}$ with a mean of $156 \mathrm{mBq} \mathrm{L}^{-1}$, respectively (Table2). In general, the gross beta activity was higher than the alpha activity concentration in the investigation area. The beta values of Sandıklı $\left(280 \mathrm{mBq} \mathrm{L}^{-1}\right)$ and Gökçealan (330 $\left.\mathrm{mBq} \mathrm{L}^{-1}\right)$ are high due to the volcanic rocks which is composed of andesite, basalt, tuff, tuffite. Also, the gross alpha and beta activity values in dry period higher than the rainy period. All the values of alpha and beta activity in the selected water samples were lower than the permissible limits for WHO [33].

\section{Conclusions}

This study used groundwater chemistry and isotope data to investigate the residence time of groundwater in the Quaternary porous aquifer system in the Sandıklı basin.

The hydrogeochemical facies of groundwater are " $\mathrm{CaMgHCO}_{3}$, $\mathrm{CaHCO}_{3}, \mathrm{CaMgHCO}_{3} \mathrm{SO}_{4}$ and $\mathrm{CaMgSO}_{4} \mathrm{HCO}_{3}$. All of the groundwater flow system is recharged by meteoric water. Low tritium, low temperature, low electrical conductivity, and low $\mathrm{Cl}^{-}$values were obtained in the region. However, sample 2 have high temperature and high electrical conductivity values in the region show that this groundwater has deep circulation and long residence time due to the sample was effected from the Hudai geothermal region. Generally, the tritium values in water samples were recharged after 1952 and the waters are "submodern" category. The d-excess indicates that low evaporative and rainfall the primary source of recharge in the study area. The gross alpha and beta activity concentrations were below the values recommended by WHO. The drinking waters in the basin are high quality waters and safe in terms of natural radioactivity. The waters are suitable for drinking, domestic use and generally for irrigation.

\section{Acknowledgement}

For their contributions in this study, the writers thank the Research Fund of the Suleyman Demirel University. Project Number: 1545-D-07.

\section{References}

[1] Chen Z, Nie Z, Zhang G, Wan L, Shen J. "Environmental isotopic study on the recharge and residence time of groundwater in the Heihe River Basin, northwestern China". Hydrogeology Journal, 14, 1635-1651, 2006.

[2] Subyani AM. "Use of chloride-mass balance and environmental isotopes for evaluation of groundwater recharge in the alluvial aquifer, Wadi Tharad, West Saudi Arabia". Environmental Geology, (46), 741-749, 2004.

[3] Gupta SK, Deshpande RD. "Groundwater isotopic investigations in India: What has been Learned?". Current Science, 89(5), 826-830, 2005.

[4] Clark ID, Fritz P. Environmental Isotopes in Hydrogeology. Lewis, Boca Raton, FL, CRC Pres, 1997.

[5] Bowen GJ. "The Online Isotopes in Precipitation Calculator". Version OIPC2.2 (7/2008) Accessible at: http://www.waterisotopes.org, (12.06.2012). 
[6] Zhu GF, Li ZZ, Su YH, Ma JZ, Zhang YY. "Hydrogeochemical and isotope evidence of groundwater evolution and recharge in Minqin Basin, Northwest China". Journal of Hydrology, 333(2), 239-251, 2007.

[7] Kinnon ECP, Golding SD, Boreham CJ, Baublys KA, Esterle JS. "Stable isotope and water quality analysis of coal bed methane production waters and gases from the Bowen Basin, Australia". International Journal of Coal Geology, 82(3), 219-231, 2010.

[8] Gastmans D, Chang HK, Hutcheon I. "Stable isotopes $(2 \mathrm{H}, 180$ and 13C) in groundwaters from the northwestern portion of the Guarani Aquifer System (Brazil)". Hydrogeology Journal, 18(6), 1497-1513, 2010.

[9] Saha D, Dwivedi SN, Roy GK, Reddy DV. "Isotope-based investigation on the groundwater flow and recharge mechanism in a hard-rock aquifer system: the case of Ranchi urban area, India". Hydrogeology Journal, 21(5), 1101-1115, 2013.

[10] Ghalib HB, Söğüt AR. "Environmental isotopic characterization of groundwater and surface water in northeast Missan Province, South Iraq". Acta Geologica Sinica (English edition), 88(4), 1227-1238, 2014.

[11] Hopkins CB, McIntosh JC, Eastoe C, Dickinson JE, Meixner T. "Evaluation of the importance of clay confining units on groundwater flow in alluvial basins using solute and isotope tracers: the case of Middle San Pedro Basin in southeastern Arizona (USA)". Hydrogeology Journal, 22(4), 829-849, 2014.

[12] Kanduč T, Grassa F, McIntosh J, Stibilj V, Ulrich-Supovec M, Supovec I, Jamnikar S. "A geochemical and stable isotope investigation of groundwater/surface-water interactions in the Velenje Basin, Slovenia". Hydrogeology Journal, 22(4), 971-984, 2014.

[13] Mokrik R, Juodkazis V, Štuopis A, Mažeika J. "Isotope geochemistry and modelling of the multi-aquifer system in the eastern part of Lithuania". Hydrogeology Journal, 22(4), 925-941, 2014.

[14] Qiu X, Zhang M, Wang S. "Preliminary research on hydrogen and oxygen stable isotope characteristics of different water bodies in the Qilian Mountains, northwestern Tibetan Plateau". Environmental Earth Sciences, 75(23), 1491, 2016.

[15] Bonotto DM, Bueno TO, Tessari BW, Silva A. "The natural radioactivity in water by gross alpha and beta measurements". Radiation Measurements, 44(1), 92-101, 2009.

[16] Zorer ÖS, Ceylan H, Doğru M. "Gross alpha and beta radioactivity concentration in water, soil and sediment of the Bendimahi River and Van Lake (Turkey)". Environmental Monitoring and Assessment, 148(1-4), 39-46, 2009.

[17] Mohammad Abdullah I, Al-ZubaidyNabil N. "Estimation of natural radioactivity in water and soil in some villages of irbid city". Applied physics research, 4(3), 39-47, 2012.

[18] Agbalagba EO, Onoja R. "Evaluation of natural radioactivity in soil, sediment and water samples of Niger Delta (Biseni) flood plain lakes, Nigeria". Journal of Environmental Radioactivity, 102(7), 667-671, 2011.

[19] Muhammad BG, Jaafar MS, Akpa TC. "A survey of gross alpha and beta activity concentrations in groundwater from Katsina area of Northern Nigeria". Radiation Protection Dosimetry, 141(2), 127-133, 2010.
[20] Turhan Ş, Özçıtak E, Taşkın H, Varinlioğlu A. "Determination of natural radioactivity by gross alpha and beta measurements in ground water samples". Water Research, 47(9), 3103-3108, 2013.

[21] Baba-Kutigi AN, Joseph E, Tikyaa EV, Sanni DM. "Investigation of the Gross Alpha and Beta Activity Concentrations of Hand Dug Well Water from Dutsin-Ma Local Government, Katsina State-Nigeria". Journal of Natural Sciences Research, 6(22), 64-70, 2016.

[22] Aksever F. Hydrogeological Investigations of the Sandıklı (Afyonkarahisar) Basin. Suleyman Demirel University, Doctoral Thesis (in Turkish-unpublished), Isparta, Turkey, 2011.

[23] Afşin M. Hydrogeological Investigation of Afyon Sandıklı Kurucay plain and Hudai spa. Ankara University, Doctoral Thesis (in Turkish-unpublished), Ankara, Turkey, 1991.

[24] Afşin M. "Hydrochemical evolution and water quality along the groundwater flow path in the Sandıklı plain, Afyon, Turkey". Environmental Geology, 31(3/4), 221-230, 1997.

[25] Afşin M, Ünsal N, Çelik M, Syed MA. "Sandıklı Kuruçay (Afyonkarahisar) ovasının yeraltı suyu bilançosu". Selçuk Üniversitesi, Mühendislik-Mimarlık Fakültesi Dergisi, 2, 10-18, 1993.

[26] Aksever F, Davraz A, Karaguzel R. "Groundwater balance estimation and sustainability in the Sandıklı Basin (Afyonkarahisar/Turkey)". Journal of Earth System Science, 124(4), 783-798, 2015.

[27] Davraz A, Afsin M, Aksever F, Karakaş Z, Hınıs MA. “The interference of a deep thermal system with a shallow aquifer and health risk assessment: the case of Sandiklı (Afyonkarahisar) Basin, Turkey". Environmental Earth Sciences, 75(4), 1-20, 2016.

[28] Aksever F, Davraz A, Karagüzel R. "Relations of hydrogeologic factors and temporal variations of nitrate contents in groundwater, Sandıklı basin, Turkey". Environmental Earth Sciences, 73(5), 2179-2196, 2015.

[29] Öngür T. "Geologic situation of Sandıklı (Afyon) geothermalinvestigation field and geothermal energy facilities". GeneralDirectorate of Mineral Research and Exploration Report No. 5520, 1973 (in Turkish-unpublished).

[30] Çakmakoğlu A. "Geology of Civril-Banaz-Sandıklı-Dinar. District (K23-c1, c2, c3, c4, d3; K24-d3, d4; L23-a2, a3, b1, b2, b3, b4; L24-a1, a2, a3, a4)". Maden Tetkik Arama Genel Müdürlüğü, Ankara, Türkiye, Report No: 8062, 1986.

[31] Piper AM. "A graphic procedure in the geochemical interpretation of water-analyses". Eos, Transactions American Geophysical Union, 25(6), 914-928, 1944.

[32] Dansgaard W. "Stable sotopes in precipitation". Tellus, 16(4), 436-468, 1964.

[33] WHO. Guidelines for Drinking Water Quality. $4^{\text {th }}$ ed. Geneva, Switzerland, World Health Organization, 2011.

[34] Freeze RA, Cherry JA. Groundwater. $1^{\text {st }}$ ed. London, Englewood Cliffs, NJ, Prentice Hall, Inc. 1979.

[35] Craig H. "Isotopic variations in meteoric waters". Science, 133, 1833-1834, 1961.

[36] Sayın M, Eyüpoğlu So. "Determination of local meteoric water lines using stable isotope contents of precipitation in Turkey". II. Use of Isotope Techniques in Hydrology Symposium, Ankara, Turkey, 26-30 September 2005. 
[37] Aggarwal PK, Basu AR, Poreda RJ, Kulkarni KM, Froehlich K, Tarafdar SA, Ali M, Ahmed N, Hussain A, Rahman M, Ahmed SR. "Isotope hydrology of groundwater in Bangladesh: implications for characterization and mitigation of arsenic in groundwater". A report on, International Atomic Energy Agency (IAEA)-TC Project BGD/8/016, Vienna, Austria, 64, 2000.

[38] Schlosser P, Stute M, Sonntag C, Munnich KO. "Tritiogenic $3 \mathrm{He}$ in shallow groundwater". Earth and Planetary Science Letters, 94(3-4), 245-256, 1988.

[39] Busenberg E, Plummer LN. "Concentrations of chlorofluorocarbons and other gases in ground water at Mirror Lake, New Hampshire". In: US Geological Survey Water Resources Investigations Report USA, 94-4015, 151-158, 1996

[40] Plummer LN, Friedman LC. Tracing and dating youn ground water: US. Dept. of the Interior, US. Geological Survey Report, US. Geological Survey Fact Sheet, USA, 13499, 4, 1999.
[41] Merlivat L, Jouzel J. "Global climatic interpretation of the deuterium-oxygen 18 relationship for precipitation". Journal of Geophysical Research: Oceans, 84(8), 5029-5033, 1979.

[42] Gleeson T, Novakowski K, Cook PG, Kyser TK. "Constraining groundwater discharge in a large watershed: Integrated isotopic, hydraulic, and thermal data from the Canadian Shield". Water Resources Research, 45(8), 1-16, 2009.

[43] Forte M, Rusconi R, Cazzaniga MT, Sgorbati G. "The measurement of radioactivity in Italian drinking waters". Microchemical Journal, 85, 998-102, 2007.

[44] Vesterbacka P. "Natural radioactivity in drinking water in Finland, Boreal". Environment Research, 12, 11-16, 2007. 